\title{
Effect of cryptorchidism on steroidogenic and mitogenic activities in rat testicular interstitial fluid
}

\author{
G. P. Risbridger, A. E. Drummond, J. B. Kerr and D. M. de Kretser
}

Department of Anatomy, Monash University, Melbourne, Victoria 3168, Australia

\begin{abstract}
Summary. There was a significant $(P<0 \cdot 05)$ and consistent increase in the potency of steroidogenic stimulatory activity (testosterone production by purified Leydig cells in vitro) in testicular interstitial fluid of the cryptorchid compared to the scrotal testis from 1 to 4 weeks after the induction of unilateral cryptorchidism. In contrast, the level of mitogenic activity $\left(\left[{ }^{3} \mathrm{H}\right]\right.$ thymidine incorporation into $3 \mathrm{~T} 3$ cells $)$ was not significantly different between interstitial fluid from cryptorchid and scrotal testes for up to 4 weeks after surgery. These results indicate that the steroidogenic activity and the mitogenic activity are due to different, as yet unidentified, factors in testicular interstitial fluid.
\end{abstract}

\section{Introduction}

Evidence for the local control of testicular function has evolved with the use of animal models of testicular damage. The effects of experimental disruption of spermatogenesis induced by vitamin $\mathrm{A}$ deficiency, X-irradiation, cryptorchidism, efferent duct ligation or heat treatment result in hypertrophy of the Leydig cells and an increased ability to secrete testosterone in vitro (see Sharpe, 1984). The demonstration that these changes to Leydig cells occurred in the damaged testes in unilateral models of spermatogenic damage, whilst leaving the Leydig cells in the contralateral untreated testis unchanged, suggested a paracrine mechanism of regulating Leydig cell function (Risbridger $e t$ al., $1981 \mathrm{a}, \mathrm{c}$ ). The identities of the agents by which this control is exerted between the tubules and Leydig cells are unknown. Nevertheless, there are reports of factors present in testicular interstitial fluid probably of tubular origin which affect Leydig cell steroidogenesis (Sharpe \& Cooper, 1984; Rommerts et al., 1986; Risbridger et al., 1986). Additionally, there is evidence to suggest that a local factor may be also responsible for regeneration of Leydig cells after the selective elimination of Leydig cells by the administration of the cytotoxic agent ethane dimethane sulphonate (EDS). Such an hypothesis was based on the observation that, after treatment with EDS and the induction of unilateral cryptorchidism, the regeneration of new Leydig cells occurred more rapidly in the cryptorchid testis (O'Leary et al., 1986; Risbridger et al., 1987).

The aims of this study were to determine the effect of unilateral cryptorchidism on the activity of a steroidogenic stimulatory factor and also of mitogenic activity (if present) in testicular interstitial fluid. These investigations were supplemented by a morphometric analysis of Leydig cells by using tissue sections from which the total volume of Leydig cells per testis was calculated.

\section{Materials and Methods}

Animal surgery and fluid collection. Mature adult male Sprague-Dawley rats were obtained from Central Animal Services, Monash University. Groups of at least 18 animals were made unilaterally cryptorchid as previously described by Risbridger et al. (1981a). At 1, 2 and 4 weeks after surgery the animals were anaesthetized with ether and perfused via the thoracic aorta with Krebs-Ringer bicarbonate buffer to remove blood from the testes to ensure that any interstitial fluid collected by draining the testes was not contaminated with blood. The testes were then excised and interstitial fluid was collected by allowing the testes to drain (from a small incision in the caudal end of the testes) for $16 \mathrm{~h}$ at $4^{\circ} \mathrm{C}$. The recovered fluid was centrifuged and treated with charcoal before storage at $-20^{\circ} \mathrm{C}$ as described 
previously (Risbridger et al., 1986). The concentrations of testosterone and progesterone in aliquants of each of these samples were also determined by radioimmunoassay (Risbridger et al., 1986).

Bioassay of steroidogenic stimulatory activity. The bioassay is based on the ability of interstitial fluid to cause a dose-dependent stimulation of testosterone production by Percoll-purified Leydig cells as previously described by Sharpe \& Cooper (1984) and Risbridger et al. (1986). Briefly, interstitial cells were obtained by collagenase digestion of adult male rat testes and layered onto a discontinuous gradient of Percoll. After centrifugation, the purified Leydig cells were harvested, placed in multiwell culture plates $\left(5 \times 10^{4}\right.$ cells/well), and incubated with test substances for $20 \mathrm{~h}$ at $32 \mathrm{C}$. Pools of fluid were obtained by combining equal volumes of interstitial fluid from individual animals in a group $(\mathrm{N}=\sim 10)$. These samples were then asayed in a single experiment in triplicate at multiple dose levels, utilizing the same preparation of Leydig cells. The relative potencies of the interstitial fluid preparations were then determined using parallel-line bioassay statistics (Finney, 1971). The activity of control interstitial fluid from untreated rats was arbitrarily defined as $1 \mathrm{unit} / \mathrm{ml}$.

Bioassay of mitogenic activity in testicular interstitial fluid. The bioassay of mitogenic activity is based on the ability of testicular interstitial fluid to stimulate the incorporation of $\left[{ }^{3} \mathrm{H}\right]$ thymidine into $3 \mathrm{~T} 3$ cells as described by Feig et al. (1980). Briefly, mouse BALB/c 3 T3 embryo fibroblasts (a gift from Dr C. Lloyd, Ludwig Institute, Melbourne, Australia) were maintained at $37^{\circ} \mathrm{C}$ in Dulbecco's modified Eagle's medium (DMEM) (Flow Laboratories, McLean, VA U.S.A.), supplemented with glucose $(4.5 \mathrm{~g} / \mathrm{l}), 10 \%$ calf serum (Gibco, OH, U.S.A.), penicillin ( $50 \mathrm{units} / \mathrm{ml})$ and streptomycin sulphate $(50 \mu \mathrm{g} / \mathrm{ml}$ : CSL, Melbourne, Australia). Monolayers of 3T3 cells were trypsinized and suspended in DMEM containing $10 \%$ calf serum at a concentration of $5 \times 10^{4}$ cells $/ \mathrm{ml}$. Samples of $200 \mu \mathrm{l}$ were placed into $96-w e l l$ culture plates (Linbro, Flow Laboratories) and incubated for 4 days without change of medium, during which time the cells became confluent and quiescent. Before the addition of interstitial fluid the monolayers were incubated overnight in DMEM containing $0.5 \% \mathrm{FCS}$. Aliquots of poois of interstitial fluid were incubated at multiple dilutions in replicates of 3 or 4 for $20 \mathrm{~h}$ at $37^{\circ} \mathrm{C}$. [ $\left.{ }^{3} \mathrm{H}\right]$ thymidine (sp. act. $6.7 \mathrm{Ci} / \mathrm{mmol}$ : NEN, Boston, MA, U.S.A.) was then added to the cells $(4 \mu \mathrm{Ci} / \mathrm{ml})$ and incubated for a further $2 \mathrm{~h}$. The cells were fixed in absolute methanol, washed with water, extracted with $5 \%$ trichloroacetic acid and lysed and dissolved in $0.3 \mathrm{M}-\mathrm{NaOH}$ and counted.

The dose-response effects of interstitial fluid were assessed for linearity and parallelism and the potencies relative to that of interstitial fluid from contralateral scrotal testes were determined. The activity of control interstitial fluid was again defined as 1 unit/ml.

Histology and morphometric analysis. The testes of 3 rats from each group were perfusion fixed with a buffered mixture of glutaraldehyde-formaldehyde. Fixed testes were decapsulated, their volumes measured by water displacement and small tissue blocks were post-fixed in osmium tetroxide, dehydrated in ethanol and embedded in Epon-araldite. Blocks were orientated to ensure that, when cut at $1 \mu \mathrm{m}$ using an ultramicrotome, seminiferous tubules were cut tranversely. Sections were stained with toluidine blue and examined with a Leitz Orthoplan microscope using a Planapo $\times 40$ oilimmersion objective and $\times 8$ eyepieces. Quantitative analysis of the total volume of Leydig cells per testis was performed by a point-counting method using a $21 \times 21$ square eyepiece graticule providing 441 test points superimposed over the $1 \mu \mathrm{m}$ stained sections. Volumetric density of Leydig cells and the interstitial lymphatic space (representing the interstitial fluid) were measured as described earlier (Kerr \& Sharpe, 1985) by scoring the number of points falling over Leydig cells and the lymphatic space expressed as a percentage of the total number of points over each microscopic field: 133 sections (all from different blocks) from all testes were examined in which 906 randomly selected areas were scored using 399546 test points. The mean volumetric density for Leydig cells and lymphatic space from each testis was determined and the mean \pm s.d. was calculated for testes belonging to a particular group. Volumetric density of the measured components multiplied by the volume of the testis from which the sections were derived yielded an estimation of the total volume of Leydig cells and lymphatic space per testis and thus the mean \pm s.d. for total Leydig cell and lymphatic space volume was calculated for each group.

\section{Results}

The absolute volume of lymph in the testis increased significantly after 4 weeks of treatment (Table 1). The concentration of testosterone in the interstitial fluid fell after the induction of cryptorchidism and was significantly reduced at each time period $(P<0.05)$ (Table 1). Progesterone concentrations were also significantly reduced 2 and 4 weeks after cryptorchidism (Table 1).

The dose-response effects of interstitial fluid from scrotal or abdominal testes were linear and parallel (Fig. 1). The estimated relative potencies of other interstitial fluid preparations are shown in Table 2 and illustrate that at 1,2 and 4 weeks after unilateral cryptorchidism there was a significant increase $(P<0.05)$ in the testosterone-stimulating potency in the interstitial fluid from the cryptorchid testis.

The mitogenic effects of interstitial fluid from scrotal or abdominal testes also provided linear and parallel dose-response lines (Fig. 2). However, the estimated relative potencies of the preparations did not significantly change throughout the study (Table 2 ). 
Table 1. The total volume of interstitial fluid and the concentration of testosterone in testicular interstitial fluid after cryptorchidism

\begin{tabular}{ccccc}
\hline $\begin{array}{c}\text { Duration of } \\
\begin{array}{c}\text { cryptorchidism } \\
\text { (weeks) }\end{array}\end{array}$ & Testis & $\begin{array}{c}\text { Lymph vol. } \\
(\mu \mathrm{l} / \text { testis }) \dagger\end{array}$ & $\begin{array}{c}\text { Interstitial fluid } \\
\text { testosterone conc. } \\
(\mathrm{ng} / \mathrm{ml})\end{array}$ & $\begin{array}{c}\text { Progesterone } \\
(\mathrm{ng} / \mathrm{ml})\end{array}$ \\
\hline 1 & Scrotal & $30 \pm 6$ & $291 \pm 124$ & $34 \pm 12$ \\
& Abdominal & $24 \pm 10$ & $70 \pm 14^{*}$ & $21 \pm 1$ \\
2 & Scrotal & $46 \pm 12$ & $396 \pm 161$ & $25 \pm 10$ \\
& Abdominal & $46 \pm 10$ & $67 \pm 29^{*}$ & $9 \pm 1^{*}$ \\
4 & Scrotal & $51 \pm 3$ & $427 \pm 172$ & $38 \pm 5$ \\
& Abdominal & $110 \pm 21^{*}$ & $172 \pm 38^{*}$ & $11 \pm 3^{*}$ \\
\hline
\end{tabular}

Values are mean \pm s.d. $(n=5)$.

${ }^{*} P<0.05$ compared to contralateral scrotal testis. (Student's paired $t$ test).

$\uparrow$ Assessed by morphometric analysis.

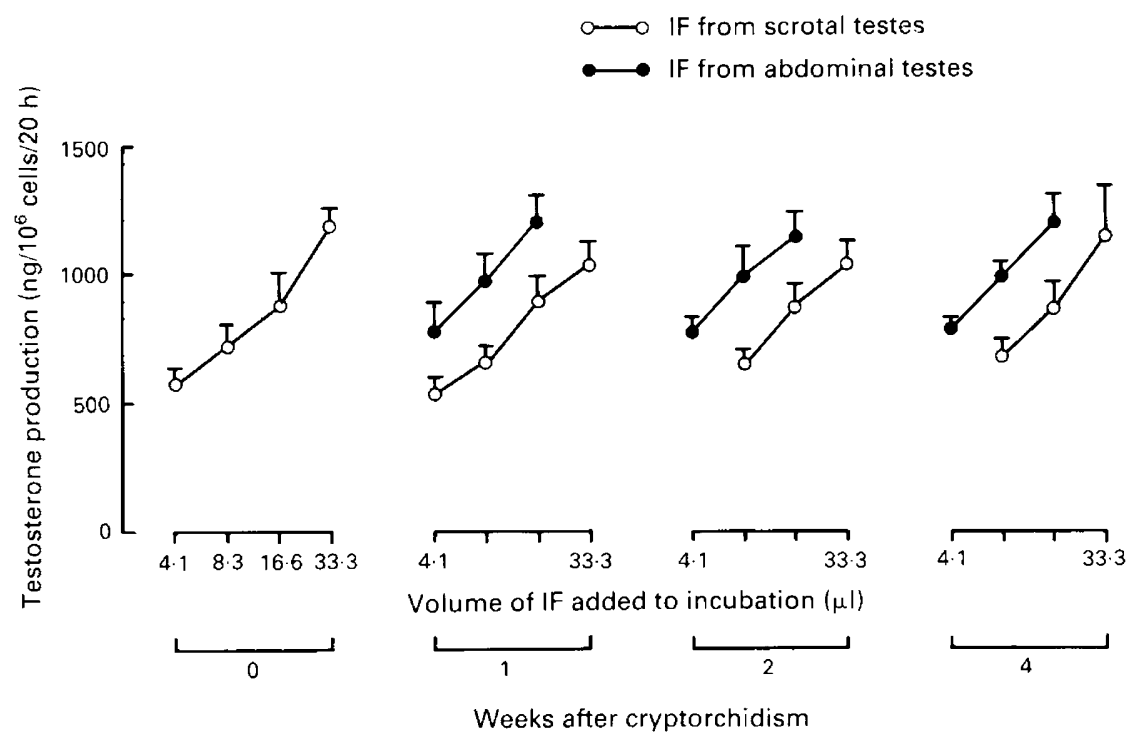

Fig. 1. The dose-response effects of interstitial fluid (IF) collected from scrotal or abdominal testes (after the induction of unilateral cryptorchidism) on testosterone production in vitro by Percoll-purified Leydig cells. Each point is the mean \pm s.d. of triplicate determinations.

Leydig cells within the testes of adult control rats exhibited a normal morphology and distribution with intertubular tissue (Fig. 3). The morphology of Leydig cells and all other components of the intertubular tissue in the scrotal testes of unilaterally cryptorchid rats was qualitatively unchanged when compared to the intertubular tissue of testes from control rats. Marked disruption of the seminiferous epithelium occurred in the abdominal testes of unilaterally cryptorchid rats, and the associated germ cell degeneration resulted in the appearance, at 4 weeks, of shrunken seminiferous tubules containing Sertoli cells and small numbers of spermatogonia. In contrast, no degenerative changes were observed in the intertubular tissue of abdominal testes. Leydig cells exhibited prominent nuclei and their cytoplasms contained numerous inclusions representing mitochondria. With the decrease in seminiferous tubular diameter, the intertubular lymphatic 
Table 2. Steroidogenic and mitogenic stimulatory activity in interstitial fluid collected from unilaterally cryptorchid rats

\begin{tabular}{|c|c|c|c|c|c|}
\hline \multirow{2}{*}{$\begin{array}{l}\text { Time after } \\
\text { unilateral } \\
\text { cryptorchidism } \\
\text { (weeks) }\end{array}$} & \multirow[b]{2}{*}{ Testis } & \multicolumn{2}{|c|}{ Steroidogenic activity } & \multicolumn{2}{|c|}{ Mitogenic activity } \\
\hline & & $\begin{array}{l}\text { Potency } \\
\text { (units/ml) }\end{array}$ & $\begin{array}{l}95 \% \text { confidence } \\
\text { limits }\end{array}$ & $\begin{array}{l}\text { Potency } \\
\text { (units } / \mathrm{ml} \text { ) }\end{array}$ & $\begin{array}{c}95 \% \text { confidence } \\
\text { limits }\end{array}$ \\
\hline 0 & & $\begin{array}{c}1.00 \\
\text { (by definition) }\end{array}$ & & $\begin{array}{c}1.00 \\
\text { (by definition) }\end{array}$ & \\
\hline 1 & $\begin{array}{c}\text { Scrotal } \\
\text { Abdominal }\end{array}$ & $\begin{array}{l}0.78 \\
2 \cdot 51^{*}\end{array}$ & $\begin{array}{l}0.59-1.04 \\
1.89-3.39\end{array}$ & $\begin{array}{l}1 \cdot 38 \\
1 \cdot 18\end{array}$ & $\begin{array}{l}1.09-1.79 \\
0.93-1.48\end{array}$ \\
\hline 2 & $\begin{array}{c}\text { Scrotal } \\
\text { Abdominal }\end{array}$ & $\begin{array}{l}0 \cdot 81 \\
2 \cdot 15^{*}\end{array}$ & $\begin{array}{l}0.61-1.04 \\
1.64-2.80\end{array}$ & $\begin{array}{l}1.07 \\
0.99\end{array}$ & $\begin{array}{l}0.85-1 \cdot 35 \\
0.79-1.24\end{array}$ \\
\hline 4 & $\begin{array}{c}\text { Scrotal } \\
\text { Abdominal }\end{array}$ & $\begin{array}{l}0 \cdot 98 \\
2 \cdot 37^{*}\end{array}$ & $\begin{array}{l}0.73-1 \cdot 32 \\
1.81-3.17\end{array}$ & $\begin{array}{l}1 \cdot 35 \\
1 \cdot 20\end{array}$ & $\begin{array}{l}1 \cdot 10-1 \cdot 70 \\
0.96-1.53\end{array}$ \\
\hline
\end{tabular}

${ }^{*} P<0.05$ compared to contralateral scrotal testis (based on the failure of the $95 \%$ limits to overlap the mean value).

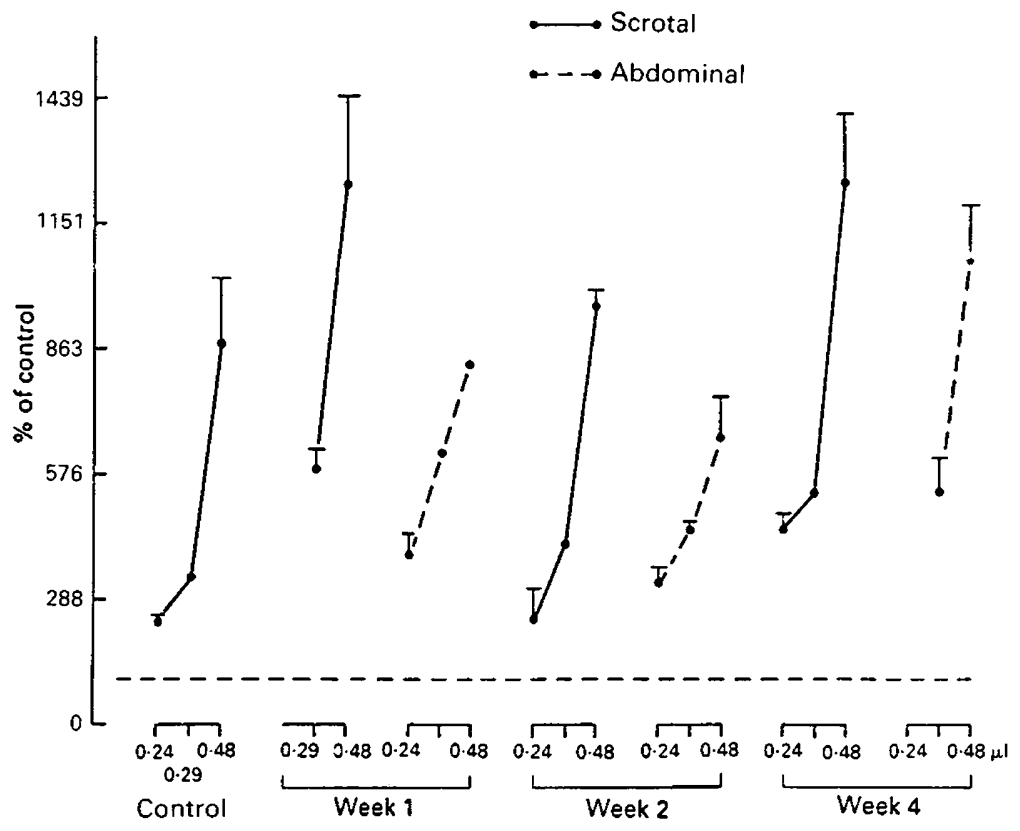

Fig. 2. The dose-response effects of interstitial fluid from unilaterally cryptorchid rats on the incorporation of $\left[{ }^{3} \mathrm{H}\right]$ thymidine by confluent, quiescent $3 \mathrm{~T} 3$ cells. The broken horizontal line represents the incorporation of $\left[{ }^{3} \mathrm{H}\right]$ thymidine by $3 \mathrm{~T} 3$ cells incubated in medium alone: this control value was designated as $100 \%$. Each point is the mean volume \pm s.d. of triplicate or duplicate determinations.

Fig. 3. Normal testicular tissue from an intact control rat, illustrating a Leydig cell (L) and a macrophage $(\mathrm{M}) . \times 340$.

Fig. 4. Abdominal testis of a 1-week unilaterally cryptorchid rat. Leydig cells $(\mathrm{L})$ are frequently aggregated to form clusters. Macrophages $(M)$ are shown. $\times 340$.

Fig. 5. Abdominal testis of a 2 -week unilaterally cryptorchid rat, illustrating Leydig cells (L) and the extensive areas of lymphatic sinusoids containing interstitial fluid (IF). $\times 340$.

Fig. 6. Abdominal testis of a 4-week unilaterally cryptorchid rat, showing many Leydig cells (L), occasional macrophages (M) and abundant interstitial fluid (IF). $\times 340$. 

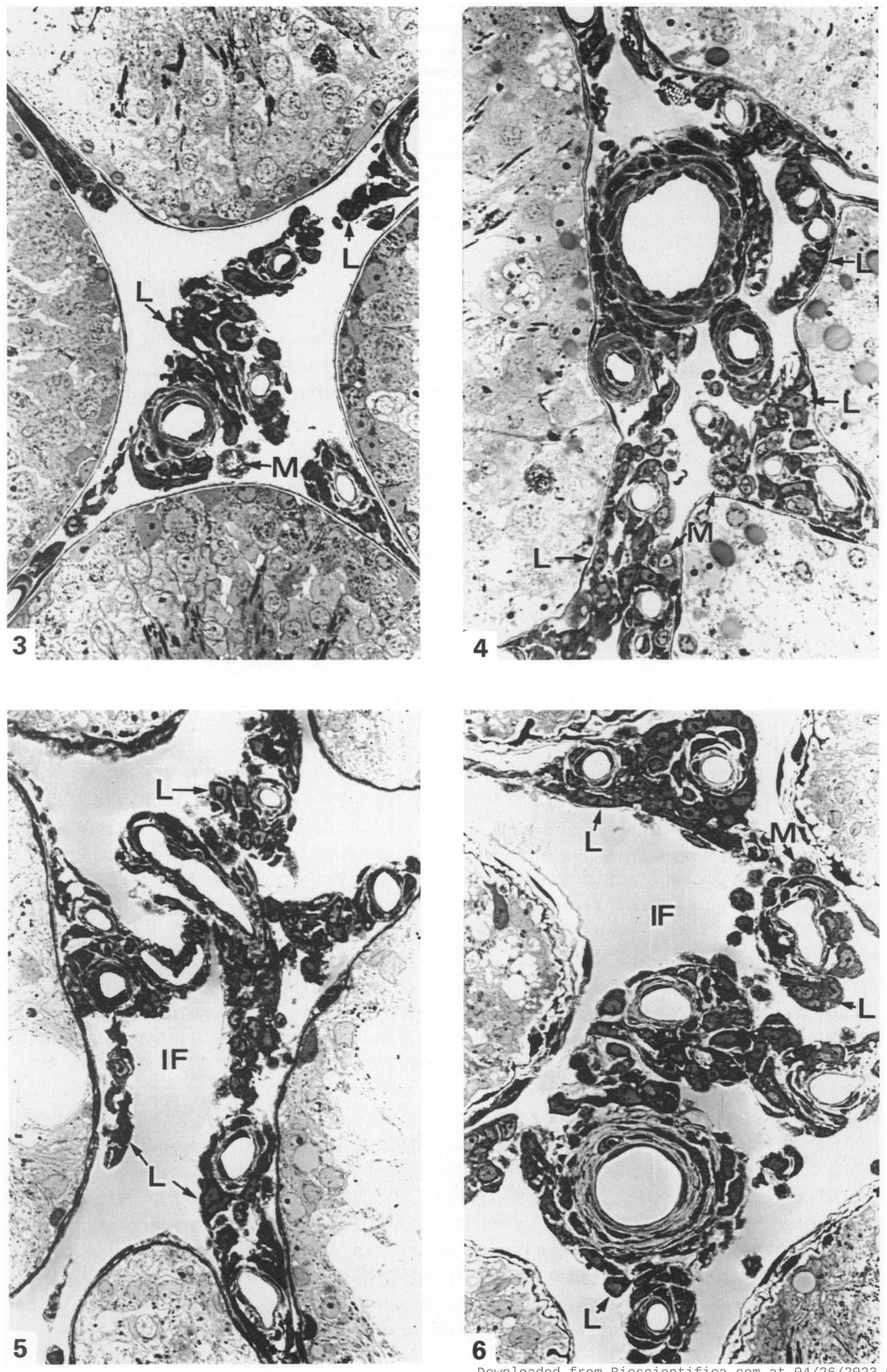
Table 3. Total volume of Leydig cells/testis after the induction of unilateral cryptorchidism

\begin{tabular}{ccc}
\hline $\begin{array}{c}\text { Duration of } \\
\text { cryptorchidism } \\
\text { (weeks) }\end{array}$ & \multicolumn{2}{c}{ Volume of Leydig cells $(\mu 1 /$ testis) } \\
\cline { 2 - 3 } & Scrotal & Cryptorchid \\
\hline 1 & $40 \cdot 1 \pm 4 \cdot 8$ & $37 \cdot 5 \pm 6 \cdot 1$ \\
2 & $33 \cdot 9 \pm 5 \cdot 0$ & $31 \cdot 1 \pm 5 \cdot 7$ \\
4 & $35 \cdot 3 \pm 5 \cdot 0$ & $31 \cdot 3 \pm 1 \cdot 9$ \\
\hline
\end{tabular}

Values are mean \pm s.d. for 3 animals.

spaces appeared widened and Leydig cells were preferentially clustered around blood vessels or formed aggregations associated with networks of connective tissue (Figs 4-6).

The total volume of Leydig cells present in scrotal and abdominal testes did not alter significantly between 1 and 4 weeks after unilateral cryptorchidism (Table 3).

\section{Discussion}

This study demonstrates the presence of mitogenic activity in testicular interstitial fluid which stimulates DNA synthesis in confluent quiescent BALB/c 3T3 cells. However, the potency of this mitogenic activity in the cryptorchid testis does not significantly change compared to that of the contralateral scrotal testis for up to 4 weeks after the induction of unilateral cryptorchidism. In contrast, the potency of steroidogenic stimulatory activity in the interstitial fluid of the cryptorchid testis is consistently and significantly increased compared to that of the contralateral scrotal testis throughout the study. These results suggest that these activities in testicular interstitial fluid are due to the presence of different substances.

The presence of steroidogenic stimulatory activity in interstitial fluid has been previously reported (Sharpe \& Cooper, 1984; Rommerts et al., 1986; Risbridger et al., 1986) and it has been shown that the stimulatory activity increases 20 days after the induction of unilateral cryptorchidism (Sharpe et al., 1986). The present study clearly demonstrates that the steroidogenic stimulatory activity results in parallel and linear dose-response lines for interstitial fluid from scrotal and abdominal testes. These results also show that the potency of this activity increased significantly 1 week after the induction of unilateral cryptorchidism. The stimulatory activity in interstitial fluid from the scrotal testes did not differ significantly from that in control testes throughout the study. The increase in steroidogenic stimulatory activity was not simply due to a decrease in the volume of testicular interstitial fluid and therefore an elevated concentration of the stimulatory activity, because the volume of interstitial fluid was shown, by morphometric analysis, to be unaltered for 1-2 weeks and then to increase after 4 weeks of cryptorchidism.

The increase in steroidogenic stimulatory activity after the induction of unilateral cryptorchidism is entirely consistent with the hypothesis that this activity may locally regulate Leydig cell steroidogenesis in vivo. It has been previously observed that the ability of the cryptorchid Leydig cells to produce testosterone in response to hCG stimulation is enhanced both in vitro and in vivo (Risbridger et al., 1981a, b). Additionally, Leydig cells isolated from cryptorchid testis synthesize more testosterone (than those isolated from normal testis) in response to stimulation by interstitial fluid collected from normal animals (Kerr et al., 1987). If more of the steroidogenic stimulatory activity is present in the cryptorchid testis and if these Leydig cells can produce more testosterone in response to interstitial fluid stimulation, it was surprising to observe significantly low concentrations of testosterone in testicular interstitial fluid. A lesion in activity of the steroidogenic enzymes converting progesterone 
to testosterone does not appear to be the cause of the decline in testosterone concentrations, because an identical pattern of change of progesterone concentrations in interstitial fluid is also observed. Nevertheless, the amount of testosterone in interstitial fluid represents $30 \%$ of the total testicular testosterone (Sharpe \& Bartlett, 1985) and the reason for the reduction in testosterone values in interstitial fluid after cryptorchidism is unknown.

Evidence for the presence of mitogenic activity in testicular interstitial fluid is presented herein and is based on the stimulation of the uptake of $\left[{ }^{3} \mathrm{H}\right]$ thymidine by confluent, quiescent BALB/c 3T3 cells. This method was first described by Feig et al. (1980) who reported the presence of mitogenic activity in the seminiferous epithelium of the mouse testis. More recently Holmes et al. (1986) have reported the presence of mitogenic activity in rat Sertoli cell culture media. Whether or not the activity in rat testicular interstitial fluid is due to the production of similar activities from the basal surface of the seminiferous epithelium is unknown.

Clegg $(1961,1965)$ has previously reported hyperplasia of the Leydig cells after the induction of cryptorchidism in the adult rat, and so it was possible that the potency of mitogenic activity in testicular interstitial fluid could be related to hyperplasia of Leydig cells and would therefore change with cryptorchidism. However, the present study failed to show any change in the total mass of Leydig cells in the cryptorchid testis and in addition we have shown that the number of Leydig cells does not alter (Kerr et al., 1987). This is in agreement with the data of Bergh \& Damber (1978) who showed that, when newborn male rats were made unilaterally cryptorchid at birth, the number of histologically recognizable Leydig cells remained unaltered at 20,30 or 100 days of age. The present study also shows that there is no alteration in mitogenic activity in testicular interstitial fluid. These observations are entirely consistent with the postulate that the absence of any change in mitogenic activity may be related to the constancy in the total mass of Leydig cells present in the cryptorchid testis. However, the in-vitro bioassay of mitogenic activity with BALB/c 3T3 cells may not be the most appropriate cell type for testing the potency of growth factors believed to act upon the cells within the interstitial tissue or seminiferous epithelium of the testis. To establish any effect of the mitogenic activity in interstitial fluid on Leydig cells, it would be necessary to use cultured Leydig cells or their precursor cell type. However, the maintenance of adult rat Leydig cells in longterm culture has been unsuccessful to date and the precise identity of the Leydig cell precursors remains to be established; nevertheless the isolation of other growth factors from the testis has relied upon the use of 3T3 cells (Feig et al., 1980; Holmes et al., 1986; Ueno et al., 1987). The present results clearly show that the potency of mitogenic activity in testicular interstitial fluid does not change with cryptorchidism and neither does the mass of Leydig cells in the testis. Further studies are required to examine whether or not mitogenic activity in interstitial fluid alters during the process of Leydig cell proliferation during sexual maturation (Tapanainen et al., 1984), after hCG stimulation (Christensen \& Peacock, 1980) or treatment with EDS (Risbridger et al., 1987).

While the source of the steroidogenic stimulatory activity in testicular interstitial fluid is unknown, it is clear from this and a previous study (Risbridger et al., 1987) that it is locally produced within the testis. Whilst it is possible that this stimulatory activity may originate from the Sertoli cell, the relationship between this activity in interstitial fluid and those reported by Parvinen et al. (1984), Janecki et al. $(1985)$, Syed et al. $(1985,1986)$ and Verhoeven \& Cailleau $(9985,1986)$ is unknown. Nevertheless, disruption of spermatogenesis and alteration of Sertoli cell function result in an increase in the concentration of stimulatory activity in testicular interstitial fluid. In contrast, the mitogenic activity in testicular interstitial fluid does not change after unilateral cryptorchidism, which indicates that these activities are different from one another. The availability of assay methods for steroidogenic and mitogenic factors within testicular interstitial fluid may be valuable in further investigations of the hormone regulation of Leydig cell function and the local control between the seminiferous tubules and the interstitial tissue.

We thank Dr C. Lloyd for valuable advice and discussion and Ms J. Muir and Mrs M. Richards for technical assistance. This study was supported by a grant from the NH \& MRC of Australia. 


\section{References}

Bergh, A. \& Damber, J.E. (1978) Morphometric and functional investigation of the Leydig cells in experimental unilateral cryptorchidism in the rat. Int. $J$. Androl. 1, 549-562.

Clegg, E.J. (1961) Further studies on artificial cryptorchidism: quantitative changes in the interstitial cells of the rat testis. $J$. Endocr. 21, 433-441.

Clegg, E.J. (1965) Studies on artificial cryptorchidism. Compensatory changes in the scrotal testes of unilaterally cryptorchid rats. J. Endocr. 33, 269-278.

Christensen, A.K. \& Peacock, K.C. (1980) Increase in Leydig cell numbers in testis of adult rats treated chronically with an excess of human chorionic gonadotrophin. Biol. Reprod. 22, 383-391.

Feig, L., Bellve, A., Horbach-Erickson, N. \& Klagsbrun, M. (1980) Sertoli cells contain a mitogenic polypeptide. Proc. natn. Acad. Sci. U.S.A. 77, 4774-4778.

Finney, D.J. (1971) Statistical Methods of Biological Assay, 3rd edn. Griffin \& Co., London.

Holmes, S.D., Spotts, G. \& Smith, R.D. (1986) Rat Sertoli cells secrete a growth factor that blocks epidermal growth factor (EGF) binding to its receptor. J. biol. Chem. 261, 40764080.

Janecki, A., Jakubowizk, A. \& Lukaszyk, A. (1985) Stimulatory effect of Sertoli cell secretory products in testosterone secretion by purified Leydig cells in primary culture. Molec cell. Endocr. 42, 235-243.

Kerr, J.B. \& Sharpe, R.M. (1985) Stimulatory effect of follicle-stimulating hormone on ray Leydig cells. A morphometric and ultrastructural study. Cell Tissue Res. 239, 405-415.

Kerr, J.B., Risbridger, G.P., Murray, P.J. \& Knell, C.M. (1987) Effect of unilateral cryptorchidism on the intertubular tissue of the adult rat testis: evidence for intracellular changes within the Leydig cells. Int. $J$. Androl. (in press).

O'Leary, P., Jackson, A. \& de Kretser, D.M. (1986) Evaluation of testicular hCG binding in unilaterally cryptorchid rats following administration of ethane dimethane sulphonate (EDS). Molec. cell. Endocr. 48, 51-58.

Parvinen, M., Nikula, H. \& Huhtaniemi, I. (1984) Influence of rat seminiferous tubules on Leydig cell testosterone production in vitro. Molec. cell. Endocr. 37, 331-336.

Risbridger, G.P., Kerr, J.B. \& de Kretser, D.M. (1981a) An evaluation of Leydig cell function and gonadotrophin binding in unilateral and bilateral cryptorchidism: evidence for local control of Leydig cell function by the seminiferous tubule. Biol. Reprod. 24, 534-540.

Risbridger, G.P., Kerr, J.B., Peake, R., Rich, K. \& de Kretser, D.M. (1981b) The temporal changes in some aspects of Leydig cell function after the induction of bilateral cryptorchidism. J. Reprod. Fert. 63, 415-423.

Risbridger, G.P., Kerr, J.B., Peake, R.M. \& de Kretser, D.M. (198lc) An assessment of Leydig cell function after bilateral or unilateral efferent duct ligation: further evidence for local control of Leydig cell function. Endocrinology 109, 1234-1241.
Risbridger, G.P., Jenkin, G. \& de Kretser, D.M. (1986) The interaction of hCG, hydroxysteroids and interstitial fluid on Leydig cell steroidogenesis in vitro. $J$. Reprod. Fert. 77, 239-245.

Risbridger, G.P., Kerr, J.B. \& de Kretser, D.M. (1987) Influence of the cryptorchid testis on the regeneration of rat Leydig cells after administration of ethane dimethane sulphonate. J. Endocr. 112, 197-204.

Rommerts, F.F.G., Hoogerbrugge, J.W. \& van der Molen, H.J. (1986) Stimulation of steroid production in isolated rat Leydig cells by unknown factors in testicular fluid differs from the effects of LH or LH-releasing hormone. J. Endocr. 109, 111-117.

Sharpe, R.M. (1984) Intragonadal hormones. Biblphy Reprod. 44, C1-L16.

Sharpe, R.M. \& Bartlett, J.M.S. (1985) The intratesticular distribution of testosterone and the relationship to the levels of a peptide that stimulates testosterone production. J. Reprod. Fert. 73, 223-236.

Sharpe, R.M. \& Cooper, I. (1984) Intratesticular secretion of a factor(s) with major stimulatory effects on Leydig cell testosterone secretion in vitro. Molec. cell. Endocr. 37, 159-168.

Sharpe, R.M., Doogan, D.G. \& Cooper, I. (1986) Intratesticular factors and testosterone secretion: the role of luteinizing hormone in relation to changes during puberty and experimental cryptorchidism. Endocrinology 119, 2089-2096.

Syed, V., Kohn, S. \& Ritzen, M. (1985) Stage-specific inhibitor of interstitial cell testosterone secretion by rat seminiferous tubules in vitro. Molec. cell. Endocr. 40, 157-164.

Syed, V., Karpe, B., Ploen, L. \& Ritzen, E.M. (1986) Regulation of interstitial cell function by seminiferous tubules in intact and cryptorchid rats. Int. J. Androl. 9, 271-284.

Tapanainen, J., Kuopio, T., Pelliniemi, L.J. \& Huhtaniemi, I. (1984) Rat testicular endogenous steroids and number of Leydig cells between the fetal period and sexual maturity. Biol. Reprod. 31, 1027-1035.

Ueno, N., Baird, A., Esch, F., Ling, N. \& Guillemin, R. (1987) Isolation and partial characterization of basic fibroblast growth factor from bovine testis. Molec. cell. Endocr. 49, $189-194$.

Verhoeven, G. \& Cailleau, J. (1985) A factor in spent media from Sertoli cell enriched cultures that stimulates steroidogenesis in Leydig cells. Molec, cell. Endocr. 40, 57-68.

Verhoeven, G. \& Cailleau, J. (1986) Specificity and partial purification of a factor in spent media from Sertoli cell-enriched cultures that stimulates steroidogenesis in Leydig cells. J. Steroid Biochem. 25, 393-402. 